\title{
A PHARMACOGNOSTIC AND PHARMACOLOGICAL REVIEW ON CURCUMA PSEUDOMONTANA J.GRAHAM
}

\begin{abstract}
VANITA KANASE ${ }^{1 *}$, JYOTI D SINGH ${ }^{2}$
${ }^{1}$ Assistant Professor, Department of Pharmacology, Oriental College of Pharmacy, Sanpada, Navi Mumbai - 400 705, Maharashtra, India. ${ }^{2}$ Master of Pharmacy Student, Department of Pharmacology, Oriental College of Pharmacy, Sanpada, Navi Mumbai - 400 705, Maharashtra, India. Email: vanita.kanase@gmail.com
\end{abstract}

Received: 26 June 2018, Revised and Accepted: 23 July 2018

\section{ABSTRACT}

Curcuma pseudomontana J. Graham belongs to the family Zingiberaceae, commonly known as hill turmeric. It is an endemic to the Western and Eastern Ghats, of peninsular India. C. pseudomontana rhizome is beneficial against leprosy, dysentery, and cardiac diseases. The Savara, Bagata, and Valmiki tribes of Andhra Pradesh use tuber extracts to cure jaundice and Bagata tribes use this plant for diabetes. In the present study, the preliminary phytochemical study and antioxidant activity of the rhizome extracts of $C$. pseudomontana were evaluated. Phytochemical screening indicated that rhizomes are rich in a variety of primary and secondary metabolites such as carbohydrates, alkaloids, Vitamin C, Vitamin E, flavonoids, phenols, glycosides, and saponins. The study highlights the biochemical and ethnopharmacological significance of an endemic C. pseudomontana. The results of pharmacognostic analysis will be helpful in developing standards for quality, purity, and sample identification. The current review summarizes the pharmacognostic parameters such as macroscopic, microscopic, physicochemical constituents, fluorescence analysis, nutritive value, behavior analysis of rhizome powder, and pharmacological activities prove it is a useful medicinal plant.

Keywords: Curcuma pseudomontana J. Graham, Physicochemical properties, Endemic, Hill turmeric.

(C) 2018 The Authors. Published by Innovare Academic Sciences Pvt Ltd. This is an open access article under the CC BY license (http://creativecommons. org/licenses/by/4. 0/) DOI: http://dx.doi.org/10.22159/ajpcr.2018.v11i12.28131

\section{INTRODUCTION}

Curcuma pseudomontana is endemic to the Western and Eastern Ghats, of peninsular India. The plant found in Karnataka, Maharashtra, and Andhra Pradesh, it is potentially ornamental species and so far the $C$. pseudomontana J. Graham known only from India [1]. It is distributed widely in peninsular and extrapeninsular parts of India; Palakkad, Kottayam, Idukki, Wayanad, Malappuram, Kannur, Thiruvananthapuram, Kozhikode districts of Kerala, Kodagu district of Karnataka, Thane, Raigad, Pune, and Ratnagiri districts of Maharashtra [2-10]. The Savara, Bagata, and Valmiki tribes of Andhra Pradesh use tuber extracts to cure jaundice and Bagata tribes use this plant for diabetes [11]. Jatapu and Kaya tribes apply warm tuber paste to treat body swellings. Women of Jatapu and Savara tribes eat boiled tubers to increase lactation [12]. Khand tribes apply the tuber paste on the head for cooling effect, crushed and boiled rhizome is edible [13]. The Kukus-Mukus eat fresh tubers as a blood purifier [14]. Rhizome past used to apply to wounds and cuts [15]. C. pseudomontana rhizome is also beneficial against leprosy, dysentery, and cardiac diseases [16]. Phylogenetic relationships between Curcuma species were studied using the cytological data [17] and random amplified polymorphic DNA fingerprinting [18-20] observed that Curcuma is a paraphyletic genus in which infrageneric relationships are more complicated.

In the recent decades, peoples are more attracted toward plant origin drugs as they are highly biocompatible with lower side effects than the synthetic drugs. The average productivity and quality are not satisfactory due to slow multiplication rate, overexploitation, and habitat destruction which are probably the main drawbacks to meet the ever-increasing market demand. Further, cultivation of these wild medicinally important plants lack sufficient disease-free elite planting materials due to high susceptibility of the crop for rhizome rot, leaf spot, and bacterial wilt [21]. The essential oil of Zingiberaceae has been studied as an antimicrobial, larvicidal, and repellent. The Zingiberaceae known as a source of flavonoids and often contain tannins [22].

\section{MORPHOLOGY AND MICROSCOPY}

C. pseudomontana has, small rootstock, bearing small almond like or subglobose tubers at the ends of the fibers (but no sessile tubers); tubers pure white inside and it is edible. Leaves are uniformly green, reaching $2 \mathrm{ft}$ or more long (including the petiole), 4-6' broad, lanceolateoblong acuminate, tapering to the base, petioles 8-15 in long. Flowers are bright yellow appearing with the bracts, 2 or 3 in each bract, in autumnal central narrowly oblong spikes $2-5$ by $1-13 / 4$ "; peduncles $3-4$ in long embraced by leaf sheaths; flowering bract $1 \frac{11 / 4}{4}-1 / 4$ by $5 / 8-7 / 8$ ", obovate-lanceolate, the lowest with purple edges only. The inflorescence of $C$. pseudomontana is lateral in the early part of the rainy season and terminal later in the season. The color of the coma is variable within the species. Flowering starts from June and ends in September [23].

Microscopic observation illustrates that T.S of rhizome shows an outermost single layered epidermis and wide central stellar region occupying $2 / 3^{\text {rd }}$ the area of the section. It contain single celled trichome. The cortex is multilayered, wider, parenchymatous cells containing starch grains, oleoresin cells, and prism-shaped calcium oxalate crystals. Vascular bundles are collateral, conjoint, closed, and scattered. Xylem vessels are spiral shaped. Fibers occur in the groups and found associated with vessels. Xylem vessel walls were thin marked with numerous pits. Powder microscopy shows that the presence of spherical-shaped xylem vessels, fibers, and varying size of starch grains in the rhizome [24,25] (Figs. 1 and 2).

\section{TAXANOMICAL CLASSIFICATION [26]}

Kingdom: Plantae

Phylum: Tracheophyta

Class: Liliopsida

Order: Zingiberales

Family: Zingiberaceae

Scientific name: Curcuma pseudomontana J. Graham

Common name(s)

English: Hill turmeric 


\section{NOMENCLATURE}

Hindi: Kachura

Marathi: सनहळद raanhalada, शदिळबान shindalavana or शदिळबानी shindalavani

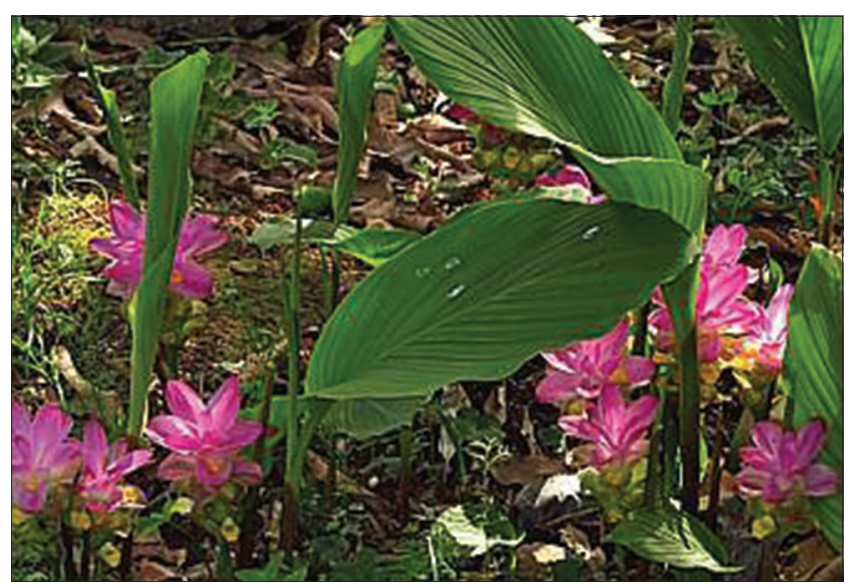

Fig. 1: Habitat of Curcuma pseudomontana

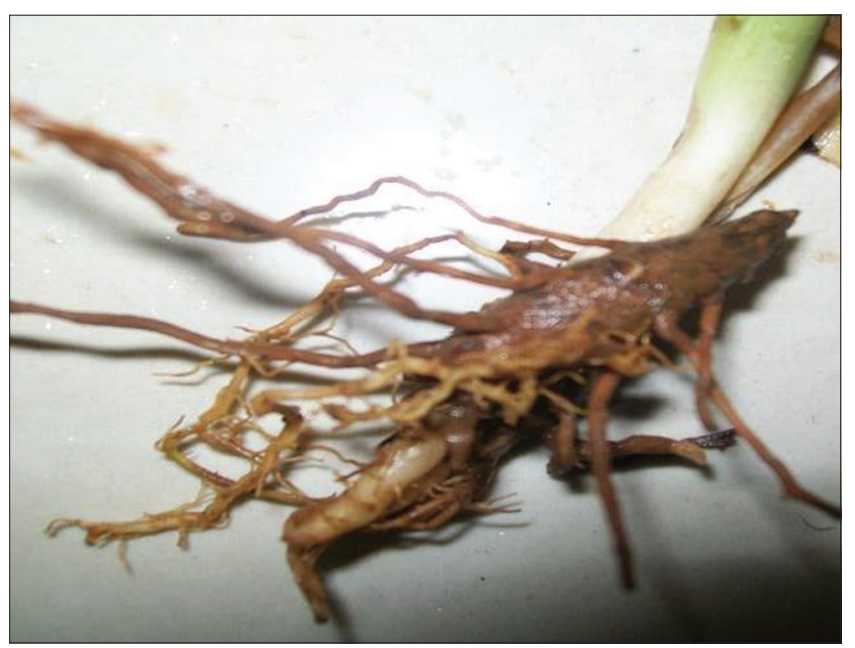

Fig. 2: Rhizome of Curcuma pseudomontana

Table 1: Physicochemical analysis

\begin{tabular}{lll}
\hline Sr. no. & Physicochemical parameter & Result $\% \mathbf{~ ( w / w ) ~}$ \\
\hline 1 & Ash value & \\
& Total ash value & 13.98 \\
& Water-soluble ash value & 4.25 \\
& Acid-insoluble ash value & 1.40 \\
& Extractive value & \\
& Chloroform extractives & 2.0 \\
& Alcohol-soluble extractives & 13.68 \\
& Water-soluble extractives & 18.95 \\
& Moisture content & 4.0 \\
3 & pH & 3.8 \\
4 & & \\
\hline
\end{tabular}

Tamil: Kattumanjal

Malayalam: Kattumanjal

Ayurveda: Tavaksheera

Telugu: Adavi pasupu

\section{Synonyms [27]}

Curcuma grahamiana Voigt

Curcuma ranadei Prain

\section{Habitat}

This species is a rhizomatous herbaceous perennial, which is found in usually moist shady places on the fringes of wet forests or grasslands, in riparian areas, at moderately high altitude along the western side of the Western Ghats [28]. The taxon occurs both in moist deciduous forest and semi-evergreen forest [29]. Mycorrhizal associations have been found [30]. Curcuma is a taxonomically difficult genus and problematic for plant hunters, herbarium technicians, as well as taxonomists. This taxon, originally described from the Western Ghats, has a confused taxonomy as it closely resembles C. montana for the side corms. C. pseudomontana and C. montana share many common floral and vegetative characters and occur in similar habitats. The inflorescence of $C$. pseudomontana is lateral in the early part of the rainy season and terminal later in the season. The color of the coma is variable within the species [28]. Molecular marker-based genetic diversity analysis has not yet been conclusive on the legitimacy of both taxa as species. A close relook into the morphotaxonomic traits of the two species is warranted before according a permanent separate status to them [30].

\section{PHARMACOGNOSTIC EVALUATION}

It is known that plants are rich in a variety of secondary metabolites such as tannins, terpenoids, alkaloids, flavonoids, phenols, steroids, glycosides, saponins, and volatile oils. It is necessary to identify the phytochemical components of local medicinal plants usually employed by herbalists in the treatment of diseases [31].

Phytochemical screening of the rhizome extracts of C. pseudomontana revealed the presence of different phytochemicals. Indeed, phytochemical investigations of this plant have resulted in occurrences of carbohydrates, alkaloids, glycosides, saponins, flavonoids, phenols, Vitamin E, and Vitamin C. The qualitative analysis of carbohydrates (Benedict's reagent test) and glycosides (Borntrager's reagent) was carried out in all extracts, i.e., aqueous (s1), methanol (s2), acetone (s3), and chloroform (s4) extracts. The solutions turning red and pink confirmed the presence of carbohydrates and glycosides, respectively. The hydrophilic carbohydrates and glycosides were present in water, whereas hydrophobic carbohydrates and glycosides were detected in rest of the organic solvents (s2, s4). The Mayer's test of extract (S2) displayed appearance of white turbidity for alkaloids. The alkaloids were absent in S1, S3, and S4 extracts. The dark brown coloration test for phenols was observed in S2-S4 extracts. The water-soluble phenols were absent in all the extracts. The extracts $\mathrm{S} 1-\mathrm{S} 4$ were shaken with distilled water. The persistence of froth in S1 and S2 was observed, indicated the presence of saponins. The hydrophilic flavonoids were detected in extract S1. The water-soluble Vitamin C was found in S1 and the Vitamin E was qualitatively analyzed by high-performance liquid chromatography method in extracts $\mathrm{S} 3$ of $C$. pseudomontana. The rhizome powder of $C$. pseudomontana showed the presence of steroids, tannins, starch, alkaloids, flavonoids, and protein [32]. Flavonoids such as luteolin, rutin, epigenin, saponins, hesperidin, and coumaric acid by

Table 2: Fluorescence analysis

\begin{tabular}{lllll}
\hline Sr. no. & Treatment & Visible light & UV short (254 nm) & UV long (365 nm) \\
\hline 1 & Powder & Brown & Brown & Brown \\
2 & Powder+NaOH & Pale yellow & Yellowish-green & Dark blue \\
3 & Powder+1N HCl & Pale orange & Dark brown & Brown \\
4 & Powder+nitric acid & Pale yellow & Pale green & Dark green \\
5 & Powder+sulfuric acid & Brownish-red & Brown & Blackish-brown \\
\hline
\end{tabular}


high-performance thin-layer chromatography revel strong medicinal value in all the rhizome extracts [33].

\section{PHYSICOCHEMICAL EVALUATION [34]}

Physicochemical evaluation of the rhizome of $C$. pseudomontana is given in Table 1.

\section{FLUORESENCE ANALYSIS $[35,36]$}

Fluorescence analysis of the rhizome of $C$. pseudomontana is given in Table 2.

\section{ANALYSIS OF NUTRITIVE VALUE AND MINERAL CONTENT [37]}

Nutritive value and mineral contents are given in Table 3.

\section{BEHAVIOR OF C. PSEUDOMONTANA [38]}

Behavior of C. pseudomontana is given in Table 4.

\section{TRADITIONAL USE}

Rhizomes of C. pseudomontana are said to be a traditional source, used in the treatment of leprosy, dysentery, cardiac disease, jaundice, diabetes, lactation antimicrobial, and antioxidant. In terms of traditional medicinal uses, they have been used for the treatment of enlarged liver, spleen, stomach ulcer, diabetes, cough, hepatic disorders, chest pain, skin diseases, boils, blood purifier, and rheumatism [39-42].

Curcumin is primary active compound of all curcuma plant, it is responsible for yellow color of curcuma [43], older investigation shows that curcumin has antimicrobial [44-46], anti-inflammatory [47], dyspepsia and gastric ulcer [48], irritable bowel syndrome [49-51], pancreatitis, rheumatoid arthritis [52,53], osteoarthritis [54], and antioxidant [55].

\section{PHARMACOLOGICAL ACTIVITY}

\section{Antimicrobial activity}

All extracts of rhizome of $C$. pseudomontana were screened in vitro for their antimicrobial activities against clinically isolated bacterial and fungal strains such as Staphylococcus aureus, Salmonella typhi, Escherichia coli, and Aspergillus terreus. In result, it is found that methanolic extract showed $4 \mathrm{~mm}$ zone of inhibition against $S$. typhi, $6 \mathrm{~mm}$ against $S$. aureus, and $8 \mathrm{~mm}$ against $E$. coli. There were $2 \mathrm{~mm}$

Table 3: Nutritive value and mineral content

\begin{tabular}{lll}
\hline Sr. no. & Element & Elemental content \\
\hline 1 & $\mathrm{~N}$ & $1.63 \%$ \\
2 & $\mathrm{P}$ & $0.134 \%$ \\
3 & $\mathrm{~K}$ & $2.194 \%$ \\
4 & $\mathrm{Na}$ & $0.197 \%$ \\
5 & $\mathrm{~S}$ & $0.253 \%$ \\
6 & $\mathrm{Ca}$ & $0.905 \%$ \\
7 & $\mathrm{Mg}$ & $0.368 \%$ \\
8 & $\mathrm{Cu}$ & $15.4 \mathrm{ppm}$ \\
9 & $\mathrm{Zn}$ & $121.1 \mathrm{ppm}$ \\
10 & $\mathrm{Fe}$ & $314.89 \mathrm{ppm}$ \\
11 & $\mathrm{Mn}$ & $255.35 \mathrm{ppm}$ \\
\hline
\end{tabular}

zone of inhibition in acetone, $6 \mathrm{~mm}$ in methanol, and aqueous against A. terreus. There were no zone of inhibition in chloroform against all the microorganisms and acetone as well as aqueous against Salmonella typhi, S. aureus, and E. coli conducted by Begam et al. [56].

\section{Antitubercular activity}

Rhizome extract exhibited significant antitubercular activity against Mycobacterium tuberculosis H37 RV conducted by Hiremath et al. [57].

\section{Anticancer activity}

Cancer is the second leading cause of death in the world [58]. Plants play an important role as a source of effective anticancer agents. Currently, over $60 \%$ of anticancer agents are derived from natural sources including plants, marine organisms, and microorganisms [59]. Different extracts of $C$. pseudomontana contain certain types of active compounds; these active compounds show anticancer activity. These active compounds are extracted with appropriate solvent (organic/ inorganic). Selection of solvent depends on the type of active compound conducted by Bisht et al. [60].

\section{Antifertility activity}

Methanolic extract of $C$. pseudomontana showed antifertility activity. However, when compared to both Curcuma longa and C. pseudomontana, C. longa is shown more significant. In spermatogenic activity, there is no significance at lower dose of $100 \mathrm{mg} / \mathrm{kg}$ bw of C. pseudomontana compared to higher dose of $200 \mathrm{mg} / \mathrm{kg}$ bw of C. pseudomontana and C. longa. The anti-implantation and abortifacient activity also showed more significance with C. longa $200 \mathrm{mg} / \mathrm{kg}$ bw when compared to other treatment groups conducted by Promod Reddy et al. [61].

\section{CONCLUSION}

C. pseudomontana is very useful for treating various types of disease, various studies have demonstrated that C. pseudomontana possess antioxidant, anti-inflammatory healing, antimicrobial, and anticancer activity. The chemical constituents such as phenolic acid, flavonoid, and other important constituents are responsible for these activities. Review of the literature concluded that $C$. pseudomontana is considered to be useful herbal medicinal plant.

\section{ACKNOWLEDGMENT}

We are grateful to our Principal Dr. (Mrs.) Sudha Rathod, Prof. Imtiyaz Ansari for their guidance and support as well as to Pharmacology Department, Oriental College of Pharmacy, Navi Mumbai.

\section{AUTHORS' CONTRIBUTIONS}

We declare that this work was done by the authors named in this article and all liabilities pertaining to claims relating to the content of this article will be borne by the authors. Miss. Jyoti Singh collected the data and analyzed the data. Dr. (Mrs.) Vanita Kanase proofread the whole manuscript, and suggested the necessary changes, and helped in designing manuscript.

\section{CONFLICTS OF INTEREST}

The authors declare that there are no conflicts of interest regarding the publication of this paper.

Table 4: Behavior of Curcuma pseudomontana

\begin{tabular}{|c|c|c|c|c|c|c|c|c|c|c|c|c|}
\hline Species name & Ext. & Car. & Sta. & Prot. & Glyc. & Alk. & Sapo. & Tan. & Flav. & Phe. & Vit C. & Vit. E \\
\hline \multirow{4}{*}{ Curcuma pseudomontana } & WE & +++ & - & - & ++ & - & ++ & - & ++ & + & ++ & - \\
\hline & $\mathrm{ME}$ & ++ & ++ & ++ & + & +++ & + & $\mathrm{GT}++$ & +++ & ++ & - & - \\
\hline & $\mathrm{CE}$ & ++ & - & - & + & - & - & - & ++ & - & - & ++ \\
\hline & $\mathrm{AE}$ & ++ & - & - & + & - & - & - & ++ & - & - & - \\
\hline
\end{tabular}

Ext: Extract, Car: Carbohydrate, Sta: Starch, Prot: Protein, Glyc: Glycoside, Alk: Alkaloids, Sap: Saponins, Tan: Tannin, Flav: Flavonoids, Phe: Phenols, Vit C: Vitamin C,

Vit E: Vitamin E, WE: Water extract, ME: Methanol extract, CE: Chloroform extract, AE: Acetone extract, GT: Gallotannins, +: Significant, ++: Moderate, +++: Very good 


\section{REFERENCES}

1. Tyag DK. Pharma Forestry A Field Guide to Medicinal Plants. New Delhi, India: Atlantic Publishers \& Distributors; 2005.

2. Hooker JD. The flora of British India. J AOAC 1882;32:291-4.

3. Cook T. The Flora of the Presidency of Bombay. Vol. I-III. Calcutta: Sri Gouranga Press Pvt Ltd.; 1903.

4. Cooke T. The Flora of Presidency of Bombay. Vol. 2. London: Taylor \& Francis; 1908. p. 750.

5. Duthie JF. Flora of the Upper Gangetic Plain and of the Adjacent Siwalik and Sub Himalayan Tracts. Calcutta, India: Government Printing Press; 1911.

6. Bamer CJ. Plants of Punjab, Superintendent. Lahore, Pakistan: Government Printing; 1916.

7. Fischer CE. Flora of Anamalai Hills: Records of the Botanical Survey of India, IX, (I), Superintendent. Calcutta, India: Government Printing Press; 1921.

8. Babu CR. Herbaceous flora of Dehradun. New Delhi, India: CSIR; 1977.

9. Mathew KN. The Flora of Tamil Nadu, Carnatic III, Part III. Monocotyledons. Tiruchirapalli, India: The Ranipat Herberium; 1981-3.

10. Ugemuge NR. Flora of Nagpur District, Maharashtra. Nagpur, India: Shree Prakashan, Shankarnagar; 1986.

11. Panal SB, Ramakrishna H, Devender R. Ethnomedical studies for endemic diseases by the tribes of Munchingiputtu Mandal, Visakhapatanam district, Andhra Pradesh, India. Int J Med Arom Plants 2012;2:453-9.

12. Ramarao N, Rajendran A, Henry AN. Increasing the secretion of breast milkindigenous practices in Andhra Pradesh. Ancient Sci Life 2000;19:1-4

13. Patil MV, Patil DA. Some wilder edible plants of Nasik district (Maharashtra). Ancient Sci Life 2000;19:102-4.

14. Bhosle SV, Ghule VP, Aundhe DJ, Jagtap SD. Ethnomedical knowledge of plants used by the tribal people of Purandhar in Maharashtra, India. Ethnobotanical Leaflets 2009;13:1353-61.

15. Reddy CS, Reddy KN, Murthy EN, Raju VS. Traditional medicinal plants in Seshachalam hills, Andhra Pradesh, India. J Med Plants Res 2009;3:408-12.

16. Yoganarasimhan SN. Medicinal Plants of India. Vol. I. Karnataka, Bangalore: Interline Publishing Private Ltd.; 2014. p. 155, 330, 493.

17. Chen ZY, Chen SJ, Huang SF. Accounts of chromosomal number of Zingiberaceae (2). Guihaia 1984;4:13-8.

18. Xiao XH, Liu FQ, Shi CH, Li LY, Qin SY, Qiao CZ, et al. RAPD polymorphism and authentication of medicinal plants from Turmeric (Curcuma L.) in China [J]. Chinese Trad Herb Drugs 2000;31:209-12.

19. Kumar TR, Santhoshkumar R, Yusuf A. Morphological characters and random amplified polymorphic DNA based genetic diversity analysis of curcuma species (Zingiberaceae) from India. Int J Plant Anim Environ Sci 2016;6:37-52.

20. Ngamriabsakul C, Newman M, Cronk QB. The phylogeny of tribe Zingibereae (Zingiberaceae) based on ITS (nr DNA) and trnL-F (cp DNA) sequences. Edinburgh J Bot 2004;60:483-507.

21. Mohanty S, Parida R, Sandeep IS, Sahoo S, Nayak S. Evaluation of drug yielding potential of micropropagated Curcuma aromatic. Int J Pharm Pharm Sci 2005;7:975-1491.

22. Hartati R, Suganda AG, Fidrianny I, Ginting TM. Total flavonoid content and antimicrobial properties of four species of Zingiberaceae. Int J Pharm Pharm Sciences 2014;6:975-1491.

23. Mohanty S, Parida R, Sandeep IS, Sahoo S, Nayak S. Evaluation of drug yielding potential of micropropagated Curcuma aromatic. Int J Pharm Pharm Sci 2015;7:511-4.

24. Hartati R, Suganda AG, Fidrianny I, Ginting TM. Total Flavonoid content and antimicrobial properties of four species of Zingiberaceae. Int J Pharm Pharm Sci 2014;6:142-4.

25. Mangaly JK, Sabu M. Curcuma pseudomontana Grah. (Zingiberaceae): A revised description. Econ Tax Bot 1987;12:159-62.

26. Anonymous. Macroscopic and Microscopic Examination: Quality Control Methods for Medicinal Plant Materials. Geneva: WHO; 1998.

27. Khandelwal KR. Practical Pharmacognosy. $18^{\text {th }}$ ed. Pune: Nirali Publication; 2007. p. 10-4.

28. Available from: http://www.taxanomical classification iucnredlist.org/ details/22486190/0.

29. Available from: http://www.synonyms.theplantlist.org/about/\#wcsp.

30. Manguly JK, Sabu M. Curcuma pseudomontana: A revise description. J Econ Taxonomic Bot 1987;10:159.

31. Molur S, Walker S. Conservation Assessment and Management Plan
Workshop (C.A.M.P. III) for Selected Species of Medicinal Plants of Southern India. Foundation for Revitalisation of Local Health Traditions, Bangalore and ZOO/Conservation Breeding Specialist Group, India and Medicinal Plants Specialist Group, SSC, IUCN; 1997.

32. Deotare PW. VAM fungal association with some plants of ethnomedicinal importance. Geobios 2003;30:65-9.

33. Hiremath GB, Kaliwal BB. Pharmacogonastic evaluation of rhizome of Curcuma pseudomontana J. Graham. Int J Pharm BioSci 2014;5:242-50.

34. Jagpat S. Analysis of flavonoid by HPTLC in rhizome extract of C. pseudomontana. Eur J Biomed Pharm Sci 2015;2:588-99.

35. Pharmacopeia of Indian: Ministry of Health and family Welfare, Government of India. $4^{\text {th }}$ ed. New Delhi: Controller of Publications; 1996. p. A53, 54, 89, 95.

36. Kokashi CJ, Kokashi RJ, Sharma M. Fluorescence of powdered vegetable drugs in ultra-violet radiation. J Am Pharm Assoc 1958;47:715-7.

37. Pratt RJ, Chase CR. Fluorescence of powdered vegetable drug with particular reference to development of a system of identification. J Am Pharm Assoc 1949;38:324-33.

38. Indrayan AK, Sharma S, Durgapal D, Kumar N, Kumar M. Determination of nutritive value and analysis of mineral elements for some medicinally valued plants from Uttaranchal. Current Sci 2005;89:1252-5.

39. Sing VK, Govil GS. Recent Progress in Medicinal Plants: Ethnomedicine and Pharmacognosy. Texas: SCI Tech Publishing LIC; 2002. p. 325.

40. Abas F, Lajis NH, Shaari K, Israf DA, Stanslas J, Yusuf UK, et al. A labdane diterpene glucoside from the rhizomes of Curcuma mangga. J Nat Prod 2005;68:1090-3.

41. Saikia B, Borthakur SK. Use of medicinal plants in animal healthcare-a case study from Gohpur, Assam, Indian. J Trad Knowl 2010;9:49-51.

42. Devi NB, Singh PK, Das AK. Ethnomedicinal utilization of Zingiberaceae in the valley districts of Manipur. J Environ Sci Toxicol Food Technol 2014;8:21-3.

43. Lampe V, Milobedzka J. Studien über Curcumin. Ber Dtsch Chem Ges 1913;46:223.

44. Allen PC, Danforth HD, Augustine PC. Dietary modulation of avian coccidiosis. Int J Parasitol 1998;28:1131-40.

45. Apisariyakul A, Vanittanakom N, Buddhasukh D. Antifungal activity of turmeric oil extracted from Curcuma longa (Zingiberaceae). J Ethnopharmacol 1995;49:163-9.

46. Rasmussen HB, Christensen SB, Kvist LP, Karazmi A. A simple and efficient separation of the curcumins, the antiprotozoal constituents of curcuma longa. Planta Med 2000;66:396-8.

47. Surh YJ, Chun KS, Cha HH, Han SS, Keum YS, Park KK, et al. Molecular mechanisms underlying chemopreventive activities of antiinflammatory phytochemicals: Down-regulation of COX-2 and iNOS through suppression of NF-kappa B activation. Mutat Res 2001;480481:243-68.

48. Prucksunand C, Indrasukhsri B, Leethochawalit M, Hungspreugs K. Phase II clinical trial on effect of the long turmeric (Curcuma longa linn) on healing of peptic ulcer. Southeast Asian J Trop Med Public Health 2001;32:208-15.

49. Barbara G, De Giorgio R, Stanghellini V, Cremon C, Corinaldesi R. A role for inflammation in irritable bowel syndrome? Gut 2002;51 Suppl 1:i41-4.

50. Bundy R, Walker AF, Middleton RW, Booth J. Turmeric zextract may improve irritable bowel syndrome symptomology in otherwise healthy adults: A pilot study. J Altern Complement Med 2004;10:1015-8.

51. Camilleri M. Dyspepsia, irritable bowel syndrome, and constipation: Review and what's new. Rev Gastroenterol Disord 2001;1:2-17.

52. Gukovsky I, Reyes CN, Vaquero EC, Gukovskaya AS, Pandol SJ. Curcumin ameliorates ethanol and nonethanol experimental pancreatitis. Am J Physiol Gastrointest Liver Physiol 2003;284:G85-95.

53. Vaquero E, Gukovsky I, Zaninovic V. Anti- inflammatory properties of curcumin. Am J Physiol Gastronintest Liver Physiol 2001; 280:G1197-G1208.

54. Kulkarni RR, Patki PS, Jog VP, Gandage SG, Patwardhan B. Treatment of osteoarthritis with a herbomineral formulation: A double-blind, placebo-controlled, cross-over study. J Ethnopharmacol 1991;33:91-5.

55. Shoskes D, Lapierre C, Cruz-Correa M, Muruve N, Rosario R, Fromkin B, et al. Beneficial effects of the bioflavonoids curcumin and Quercetin on early function in cadaveric renal transplantation: A randomized placebo controlled trial. Transplantation 2005;80:1556-9.

56. Begam SR, Karthikeyan S, Arumugam M, John SA. Antibacterial activity of Curcuma pseudomontana with special reference to multi drug 
resistant pathogens. Int J Pharmacol Scree Methods 2014;4:127-30.

57. Hiremath GB, Kaliwal BB. Anti-tubercular activity of the rhizome of Curcuma pseudomontana j. Graham. Int J Pharm Health Care Res 2013;1:178-83.

58. Madhusudan S, Middle MR. The emerging role of DNA repair proteinsas predictive, prognostic and therapeutictargets in cancer. Cancer Treat Rev 2005;31:603-617.

59. Newman DJ, Cragg GM, Snader KM. Natural products as sources of new drugs over the period 1981-2002. J Nat Prod 2003;66:1022-37.

60. Bisht VS, Kandwal S, Kanan D, Som D. Anticancerous and antiproliferative/cytotoxic activity of Curcuma pseudomontana (hill turmeric) collected from the sub Himalayan region of Uttrakhand, India. Asian J Plant Sci Res 2014;4:25-31.

61. Aloor PR, Reddy KN, Goverdhan P, Reddy CH, Hariprasad M, Kumar PK, et al. Antifertility activity of C. pseudomontana in comparison with Curcuma longa. Res Rev J Botanical Sci 2018. 